\title{
THE DISCOURSE OF EID 1429AH/2011AD GREETINGS ON THE BANNERS AND BILLBOARDS IN PADANG CITY
}

\author{
Nasrullah \& Desy Mardhiah \\ Lambung Mangkurat University \& Padang State University
}

\begin{abstract}
Eid al-Fitr is special compared to other holy days of Muslims. In addition to the celebration of victory for Muslims after a month-long fasting, there is a national phenomenon that occurs ahead of the Eid al-Fitr: the flow of urban people returning to their home towns and villlages. Millions of Muslims in Indonesia return home ahead of the holy day. Padang city or Ranah Minang as the capital of West Sumatra Province is one of the destinations for those homeward-bound travelers since the city and other areas in West Sumatra are the hometowns of the Minang people. Simultaneously, in every public space in the city, banners are installed by the head of the local government, political parties, or community leaders to deliver Eid greetings. This article examines the discourse of the message on the banners in the city of Padang in relation to the reality around the place where the banners were installed, the social context, as well as the relationship between the discourses on the banners.
\end{abstract}

Keywords: Discourse, Eid Greetings

\section{INTRODUCTION}

Eid al-Fitr as a manifestation of triumph for Muslims in reaching the fitrah (purity) after observing a month-long fasting, is usually expressed through greetings --Minal 'Aidin wal Faizin (hopefully we belong to the people who return to true human nature and get happiness of the world and the hereafter)-to fellow Muslims. On that day, Muslims forgive each other and visit siblings, friends, relatives, and neighbors to strengthen silahturahmi (good relations) so as to create a new atmosphere in the family and society. If they are in the same area, Muslims are highly recommended to immediately shake hands after performing the Eid prayer so that feelings of hate and revenge can be removed to start a new chapter in life. However, if your hand shakes are deterred by the distance, the apology can be delivered by telephone, short messages, greeting cards, facebook, and twitter.

Eid al-Fitr greetings are not only delivered by ordinary people but also by the head of the local government, political parties, and community leaders to the wider community through a variety of media such as stamps, cards, 
banners, and billboards. Stamps and greeting cards bearing the image of Megawati Soekarno Putri, along with members of the legislature during the 2004 presidential election and cards bearing the face of West Java Governor, Ahmad Heryawan, were mailed to 450 thousand addresses. A number of banners and billboards showing the pictures of public figures and political parties could be found in a number of cities across Indonesia. Padang city was no exception. Almost in every corner of the city especially on the main roads, one can easily find banners and billboards with a greeting that read Happy Eid al-Fitr 1 Syawal $1432 \mathrm{AH} / 2011 \mathrm{AD}$.

Banners and billboards are one of the main media for the community leaders in the city of Padang to deliver Eid greetings to the society, including the Minang diasporas. The Minang people [or Minagkabau] are famous for their migration tradition that began centuries ago due to the Dutch policies of labor camps and the consequent upheaval in West Sumtera in the 1950s. The events prompted a massive migration of the Minangkabau to various cities in the country, particularly to Java. Besides doing trades, the Minangkabau also migrated to continue education in various universities in Java (Sairin, 2004: $53)$.

In addition to colonization and internal upheaval, the Minang chose to migrate because of a matrilineal culture of the community which is bound by ninikmamak. According to Amir (in Sairin, 2004) they never get guidance from ther mother; they only remember sitting on their father's laps. They just know how to live with their parents. Living away from home for several generations, living with tradition of going out of the batih have effects on them when they return home for the Eid.

Finally, when returning home, it is considered a vacation alone, a week or two, not to settle. It is because they themselves are not willing to hold the custom; as persons who live in modern times they want to be free and have their own rights. While in their own hometown they have no possessions, all belonging to the people and the country. The Minangkabau region nonetheless remains lovable, but not to live in. Their particular interest is its natural beauty, not the order of the society (Hamka, 1984: 58)

The Minang diasporas who celebrate Eid in their hometowns are welcomed by regional and community leaders of Padang city through banners and billboards in several main roads. These banners are generally mounted on power poles and bridges, hung on large trees by the roadside, tied on fences of government agencies and mosques, as well as on the places provided for product promotions. The figures shown in the banner range from the governor, the mayor, regional and political elites such as Susilo Bambang 
Yudhoyono, Megawati, Hatta Rajasa, Aburizal Bakri and Patrialis Akbar. However, these figures do not appear alone but often paired with a pretty influential community leaders in the town of Padang, for example Padang's Mayor with Hatta Rajasa, West Sumatra Vice Gubenur with Aburizal Bakri. There are also public figures shown singly, not leaving certain symbols such as Syarli Mubaraq and Patrialis Akbar. Products that carry certain brands such as In Mild, Win Mild, Apache, Matahari Dept. Store, Cressida, Indosat IM3, Emas Murni Store, Haluan Daily, Marquisa Drinks, Bazda, LPPOM also took part in scrambling the symbols and identity in the city of Padang.

The occasion to meet with parents, siblings or relatives, is used by the local government to show its social existence especially in terms of improving the welfare of the Community along with the turnover these homecoming travelers bring during Eid, and collecting ideas in order to advance the areas in West Sumatra. In this regard, this paper attempts to reveal the discourse of Eid greetings displayed in banners in the city of Padang. This paper is divided into several sections. The first part deals with the mapping of Eid greeting banners in Padang city; the second part outlines the discourse displayed in Eid greetings in Padang city followed by the conclusion at the end of the paper.

\section{BANNER AND BILLBOARD WAR IN THE CITY OF PADANG}

The Indonesian Language Dictionary defines a banner as cloth hung in a public place containing slogans, propaganda or news need to be delivered to the public or community, while a billboard is a large sized board that attracts the attention of people (usually with large images in a crowded place) (2008: 1333,126). Banners have a variety of sizes, ranging from small, dilated, elongated and transverse. Banners are placed at strategic spots in some corners of the city such as the crossroads, T-junctions or intersection where a lot of people pass by. The message displayed in any banners related to the purpose of the installer in order to attempt to influence others. However, the impact is up to each individual whether or not they will be affected by these banners.

The political situation ahead of the 2014elections in the city of Padang provided their own color in the form of Eid greetings for $1432 \mathrm{AH}$. Although the election is still months away, there have been many political parties seeking collaboration with like-minded parties because it is the Democrat Party that can nominate its candidates without coalition. This is because the Democrat secured 15 percent of votes or has eight seats in the parliament. Meanwhile, other political parties like PPP, Golkar, Hanura, PAN, PKS, Gerindra, PBB and PDI of Struggle are non-Parliament parties required to coalesce in order to meet the quota. The nine names for the Padang Mayor are as follows: Mahyeldi Ansyarullah (Vice 
Mayor of Padang), Desri Ayunda (Director of PT Igasar), Wahyu Iramana Putra (Padang Golkar Chief), Yendril (Padang Hanura Chief), Zulherman (Padang Parliament Speaker), Zulhefi Sikumbang (Migrant Figure), James Hellyward (Academician/Head of Padang Brotherhood Association), Aldi Yunaldi (Public Figure and Advertising Businessman, Head of WPCD), Syarli Mubaraq (Driving the reform of 1998). These names can be found in banners displaying season's greetings for Eid al-Fitr $1432 \mathrm{AH}$ in Padang city.

The banners for Eid al-Fitr $1432 \mathrm{AH}$ were propagated virtually in various corners of the city of Padang. Starting from the bypass at the entrance of Padang city, Sawahan Junction, Agussalim Street, Terandam Street, Imam Bonjol Street intersection, Bagindo Azizchan, Thamrin, Muara, A.R. Hakim, Pemuda, Ahmad Yani, Veteran, S. Parman, Sudirman, Rasuna Said intersection, Khatib Sulaiman, to Prof. Dr. Hamka street. One day before the Eid, as many as 100 pieces of banners had been installed and the number would likely continue to grow, and this paper will be limited to cover only on the day before the Eid celebration. These banners were not only mounted on the side of a trash container, nailed to a tree, stretched on fences, next to the railway, on the traffic lights of a highway, on the mosque fence, next to the bus stop, next to a police post, in front of the stall, but also placed next to or in front of the building of government agencies.

It showed that the city of Padang has been transformed into the contestation between political figures in public spaces as a political battle field during Eid al-Fitr. It is visible from a number of banners and billboards which not only displayed Eid greetings, but also --according to Irawanto (2006: 9)-- served as means of political campaigns of the City Government. As a result, the highway became a stage of the festival of a number of banners in order to expose the identity of a particular group. This, of course raises, a wide range of assumptions about the meaning of the socio-religious festival of Eid alFitr that causes an imbalance in itself that will be a social issue or an issue of 'power relations' as put forward by Michael Faucoult.

\section{THE DISCOURSE OF EID GREETING BANNERS} AND BILLBOARDS IN PADANG CITY

\section{Discourse of Greeting Banner of political parties}

Symbolically, wearing a white shirt or koko, a black cap, a sarong, Moor berkalung, putting hands together on the chest and smiling a little has become the identity the community leaders do when conveying the Eid greetings on banners. In fact, they try to display a trademark so that it has a certain religious symbol and influence to win the people's confidence. The identity that serves 
as the hallmark of the public figures and political elites of the city of Padang for the Eid al-Fitr so it can be presumed that the candidates appear to open themselves to renewing human relationships especially with communities the city of Padang.

In banners and billboards, the national figures are paired with local figures as symbols of communication with society at large. Banners or billboards featuring the Chairman of the Golkar party or the National Mandate Party, along with photographs of them, will strengthen the memory of society a these figures have been known widely through media such as the television, newspapers, magazines, and the radio.Visualization it is reinforced with colorful banners and specific attributes as symbols or identities of particular groups.

Essential elements in billboards and banners on display in a public place contains the emblem of the party and party leaders, and greetings of Eid. In billboards, Golkar party logo, the Banyan tree, was displayed at the top; Aburizal Bakrie image as the Chairman of the party with the tile of 'Haji " in the front of his name was put below the logo. The important figures of Golkar from West Sumatra, Muslim Kasim, the Chairman of the Golkar party's Advisory Council and Hendra Irwan, West Sumatra Golkar Chairman appeared at half body size. The two prominent Golkar figures of West Sumatera were placed below Aburizal Bakrie. Eid greetings in Golkar Party's billboards were on the bottom. A popular phrase delivered was "Happy Eid al-Fitr 1429 AH" in large fonts. Another message read in smaller fonts "Minal Aidin Wal Faidzin Mohon Maaf Lahir dan Batin " (literally meaning hopefully we belong to the people who return to true human nature and get happiness of the world and the hereafter; please forgive us physically and spiritually).

The same message was also featured in a banner of the Golkar party where the position of the image of the party was displayed in parallel. The party's logo was placed at the left or at the right of the banner, while party leaders namely Zailis Usman and Wahyu Irmana Putra at the right or the left of the banner. The difference was that Wahyu Irmana Putra represented the Golkar Party while Usman Zailis conveying the message as a member of the Golkar faction in the local Parliament. Their photographs looked more official as they were wearing a black cap and suits, and were placed at the right or the left of the banner. The phrase Happy Eid al-Fitr 1432 AH in large fonts. "Minal Aidin Wal Faidzin Mohon Maaf Lahir dan Batin" was written in smaller fonts.

In contrast to the Golkar party, the billboard of the National Mandate Party (PAN) displayed the greetings "Happy Eid al-Fitr 1432 AH" at the top followed by two lines below it, "Minal Aidin Wal Faidzin Mohon Maaf Lahir dan Batin". 
The PAN logo appeared above the party leaders. Figures were shown wearing a white Moslem shirt, a black cap displaying the Eid atmosphere. These figures are Dr.H.Fauzi Bahar, M.Si, Chairman of PAN of Padang city, Hatta Rajasa, the PAN General Chairman, and H. M Asli Chaidir, PAN Regional Chairman of West Sumatera with the Eid greetings below them. The Billboards and banners of the PAN displaying the image of Hatta Rajasa all the time is interesting to interpret further. In addition to the sentence that reads "13th Anniversary of PAN", a short sentence with the additional message is always shown on any banners and billboards. The more number of billboards showed that the PAN as the party that won the two elections are using billboards to disclose of the identity of its rulers.

The banners of Islamic parties found one day before the Eid in the city of Padang belonged to the United Development Party (PPP) and the Prosperous Justice Party (PKS). Both parties have different ways in displaying greetings compared to Golkar and PAN. The PPP only used banners, similar to the PKS as the party with the ideology of Islam. Although in the form of banners, the two Islamic parties displayed more messages. The PPP displayed three pictures of the party figures, Yuliarman AM, Treasurer of the party; H. Epyardi Asba, Chairman of the party with a larger image size; and H. Amora Lubis, Treasurer of the party. The PPP and the PKS did not feature the national party leaders as the appeal of the billboards. The PPP even showed more than ten party figures on the banner background with sentences that read:

\title{
“THE PPP OF WEST SUMATRA LARGE FAMILIES WISHES YOU
}

\author{
A happy Eid al-Fitr 1432 AH/2011 M \\ Minal Aidzin Wal Faidzin \\ PPP, the Great Home of Muslims!!! “
}

The party logo was placed at the right side of the banner, while the greetings in the middle or between pictures of party leaders and party logo. The same pattern was used by the PKS on their banners. Images of two West Sumatra PKS figures were at the left, namely DRS. Muhdi, General Chairman; and Mulyadi Muslim, Regional Chairman of Padang city. The middle part consists of six lines of sentences: 


\section{Regional Chairman of PKS Padang City \\ Wishes you \\ A Happy Eid al-Fitr 1432 AH}

Taqabbalallahu minna waminkum (May Allah accept it from you and us)

Please accept our apology

"Build Devotion [to God] and Advance Together to Build Padang City

Displays in the form of banners above gave the impression to illustrate the power of interpersonal relationships for the banner actors. New meaningful communication that occurred with a different banner positioned parallel to the banners with similar ideology that presented a certain social reality in society at large. The PKS banner with its Islamic identity stressing on the phrase Taqabballahu minna wa minkum in Arabic was mounted next to the Golkar banner with the addition of Islamic identity like Allahu akbar ...Allahu akbar.Allahu akbar (Allah is Great). It reflects a new political force through the banners. In the end, the two pictures intended to deliver to the people that the these banners have close ties.

\section{Discourse of Greeting Banners of Community Leaders}

The figures appearing in the Eid greeting banners in Padang city are among others, political figures with their position in the party or the position in the community organizations such as Irwan Prayitno (West Sumatera Governor), Muslim Kasim (Vice Governor, also Chairman of the Regional Advisory Council of West Sumatera, Fauzi Bahar (the Mayor of Padang, Chairman of Supervisory Council of Indonesian Pencak Silat Association (IPSI), Chairman of the Padang Brotherhood Association, Regional Chairman of PAN Padang City), Mahyeldi (Deputy Mayor of Padang), Aldi Yunaldi (Chairman of the WPDC), James Hellyward (Chairman of IKP), Wahyu Irama Putra (Regional Chairman of the Golkar party), Muhidi (General Chairman of PAN), Asli Chaidir (Regional Chairman of PAN West Sumatera), and Usman Zailis (member of the Golkar faction in the local parliament). Figures such as, Syarli Mubaraq (Migrant Figure), and Zulhefi Sikumbang (Chairman of Padang Brotherhood Association of Jakarta) also participated in the banner 'battle' in Padang city. However, the banners of the Local Governments such as the Bureau of Public Relations and Protocol, LPPOM and MUI of West Sumatra, Yamin Waisare (head of BKKBN, West Sumatera Representative), Syarlinawati Akbar (the Commissioner of PT Semen Padang) were outnumbered by the others.

In fact, the banners not only contained the Eid greetings, but also offered 
specific identity as a symbol of communication with society at large. For example 'Do your work and get sympathy' (the national mandate party --PAN); 'PPP, the Great home of Muslims (the United Development Party --PPP); Golkar's voice, people's voice' (Golkar); 'Build your devotion to build Padang City' (the Prosperous Justice Party --PKS). The identity of the same organization was displayed in different locations by carrying different slogans such as, 'Let's make peace with Fellow [human beings]' (WPCD), Let's build better relationship between citizens (WPCD), May our good relationship be Maintained for our beloved Minang homeland (KNPI); Hopefully, on the day of Fitr, we remain in good relationship (KNPI).

The banner placement showed how community leaders and the political elites reconstruct political forces in the form of apology. It could be seen in the banner installed by the Padang Brotherhood Association (IKP) side by side with the one installed by the Padang Peace-Loving Citizens (WPCD); Zulhefi Sikumbang, (Migrant Figure) next to Extra Ginseng Banner, all sending the same message of Eid greetings. The Golkar banner was placed below the Democrat Party; the PPP banner above the Democrat; the IKP next to the Golkar, Syarli Mubaraq and Patrialis Akbar; Syarli Mubaraq banner was mounted under the billboard of Fauzi Bahar (PAN); Zulhefi Sikumbang above the KNPI; Padang Peace-Loving Citizens (WPCD) parallel with Zulhefi Sikumbang, the PPP and Syarli Mubaraq; The banners belonging to the PAN, Zulhefi Sikumbang, and The Peace-Loving Citizens (WPCD) were at the same location; KNPI next to IKP; Zulhefi Sikumbang, PKS and Golkar were at the same place; Syarli Mubaraq above the Democrat; Wahyu Iramana Putra (Golkar) side by side with the billboard of Governor and Deputy Governor of West Sumatera; Fakhrizal (National Democrat of West Sumatera) next to the WPCD; Syarlinawati Akbar (the Commissioner of PT Semen Padang) side by side with Syarli Mubaraq (Migrant Figure); Zulhefi Sikumbang next to Syarlinawati Akbar. All these banners aimed to charm people and increase popularity in the midst of Padang's diverse constituents.

\section{Discourse of Eid Greetings of the Commercial Products}

A beverage sweetener product billboard in the portrait mode stood on the intersection. Everyone passing this location could easily notice the pairs of celebrities, Anang Hermansyah wearing a black cap, a white shirt, putting his hands together on the chest. Meanwhile, Ashanty was wearing a hijab and a white dress, both hands on the chest. The top left-hand corner of the the smiling couple, there was a brand of drink sweetener product that read: MARQUISA WASP HIVE JUICE. Then, greetings that read "Happy fasting \& 
Eid al-Fitr $1432 \mathrm{AH}$, the month full of devotion and kindness". In the bottom part of the couples' images were also pictures of various Marquisa products in various shapes of bottle. A curved-shaped text read, "freshness has no end ...!"

The influence of the market is inevitable in many aspects of life, and it is no exception in the religious aspects with regard to to the culture of Indonesia as in the case of returning to home towns for Eid celebration. The Marquisa Wasp hive billboard presumably utilized two religious events, i.e. Ramadan and Eid, as evidenced by the messages on the billboard. A different way of advertising was done by a cigarette company; without a lot of persuasive sentences, it simply delivered the message:

\section{Celebrate the Victory with}

In mild

\section{HAPPY EID AL-FITR 1432 AH}

The final part as always, there is a warning on cigarettes, but largely ignored by smokers, i.e. the danger of smoking to health because it can cause a variety of ailments. Among the various billboards and banners, the discourse of cigarette products is simply and clearly understood. In the form of a banner, the ads appear with a Apache tribal man and the middle part of it is a space for Eid greetings.

The banners of medicinal products also appeared with an image of the actress Nurul Arifin, and in the middle part it read "Diapet wishes you a Happy Eid, 1 Syawal 1432 AH, Forgive us physically and spiritually". The product slogan was at the right side of the banner. For certain products, their identities were clearly displayed such as, Together we build our country (Nagari Bank); Eid, Full of style, complete and money-saving Matahari Dept. Store); Awesomely cool (Cressida); Celebrate Victory together (In a Mild); Winning is an option (Win Mild); returning home with smiles (IM3). Meanwhile, the Minang diasporas were greeted with appropriate messages such as, The Local Government and Society are pleased to welcome you all (Bank Nagari); Welcome home, our relatives, the Minang diasporas, hopefully the Eid al-Fitr $1432 \mathrm{AH}$ will give us the spirit to build the Minang Homeland (West Sumatera Nagari Bank).

\section{EID BETWEEN POLITICAL DISCOURSE, COMMUNITY LEADERS AND THE MARKET}

The phenomenon of Eid banners and billboards in Indonesia, especially in Padang city can be seen from the three parties involved; political parties, 
community leaders, and the market. Political parties display pictures and texts that they try communicate to the public, especially the passers-by. The national level party figures became an icon of the two major parties: Golkar and PAN in Padang city. The space for Eid greetings occupied almost a quarter of the billboards, meaning that the discourse the party intended to bring about was to exploit the Eid celebration to further strengthen its political position. This phenomenon shows some upward-oriented culture followed by justification of what those in the upper class are doing, or idolizing any figures considered symbols of upper-class (Bungin, 2008: 48).

Islamic parties such as the PKS and PPP are likely to appear in the form of banners, presumably trying to make regional executive chiefs to appear before the public. The absence of national figures of the party, may be simply a choice or a strategy to avoid upward orientation. Despite this, the PKS and the PPP have appeal through community or kinship with the use of the phrase "the Big family ... wishes .....

So, the discourse of the two groups of parties i.e. the nationalist and Islamic, shows that the national party still has powerful patronage in the form of party leaders, while the Islamic parties focus more on the strength of kinship or locality. They are increasingly aware that language, in itself, appears as a representation of a space for the deployment various kinds of power. Therefore, language can be seen as a space where various conflicts of interests, power, and counter hegemony occur (Hikam, Latif, 1996: 77).

The discourse of leadership in the Eid-related banners or billboards, followed by persuasive phrases that seem to care about the local conditions, came from the figures affiliated with political parties. Whether It is realized or not, the proximity of the installation between banners or billboards and party leaders in the city of Padang has also shown the relation between the actors featured in banners or billboards of the Eid al-Fitr holiday. The figures that appear more have a tendency to run for office in the election the Regional Head of West Sumatra in 2014.

Behind the Eid discourse in banners and billboards, as well as in the middle of male dominance in public, should be a concern about the existence of women being displayed. Based on the observations, there were only four women in the billboards or banners in the city of Padang. Women were only present in the banners and billboards advertising products of clothing, beverages and sweeteners. The presence of women in the public sphere is still a rarity, as in the case of Padang city with the appearance of Hj Syarlinawati Akbar, S. Pd. The Eid always comes with the presence of the market. In this case the 
discourse was present through banners in Padang city advertising clothes, drinks, cigarettes and medicine. The political parties and community figures display their identity while the market is present in different way. The billboards advertising cigarettes, dresses and drinks with an invitation to the public to use such products are part of their celebration of the Eid alFitr holiday. The phenomenon of Eid-related billboards or banners shows that there are ideological influence and interest in the market. Religion tends to be understood from the outside, from the image formed by the market so it is aesthetical in nature. In the meantime, the ethical values that concern the nature of religion have been used as the source of values in the formation of a blue print for less influential life practices (Abdullah, 2006: 119).

\section{CONCLUSION}

The Eid discourse delivered through banners and billboards in the city of Padang in West Sumatra is not just a moment to celebrate the feat or to welcome the arrival of the homecoming Minang diasporas, but it has become a battle field of discourse. The presence of political parties, public figures, advertisements that seems to be part of the Eid al-Fitr holiday, turned out to have interests to competing for public attention in public spaces. The discourse they tied to deliver may vary but unfortunately it does not touch the real condition of the society. For example there are no banners or billboards installed by political parties, community leaders, as well as certain products around the hospital that give attention to the patients' recovery. So is the placement of banners or billboards, it only aims at being seen by as many people as possible.

\section{BIBLIOGRAPHY}

Abdullah, Irwan, 2006. Konstruksi dan Reproduksi Kebudayaan, Yogyakarta: Pustaka Pelajar.

Amir, MS 2004. "Pemerintahan Nagari dan Masyarakat Adat Suatu Tinjauan Kritis" dalam Bandaro, dkk Minangkabau yang Gelisah Mencari Strategi Sosialisasi, Pewarisan, Adat dan Budaya Minangkabau untuk Generasi Muda, Bandung: Lubuk Agung

Bungin, Burhan. M, 2008. Konstruksi Sosial Media Massa: Kekuatan Pengaruh Media Massa, Iklan Televisi, dan Keputusan Konsumen serta Kritik Terhadap Peter L. Berger \& Thomas Luckmann, Jakarta: Kencana

Departemen Pendidikan Nasional, 2008, Kamus Besar Bahasa Indonesia, Jakarta: Gramedia Pustaka Utama

Hamka, 1984. Islam dan Adat Minangkabau, Jakarta: Pustaka Panji Mas 
Hikam, Muhammad AS, 1996. "Bahasa dan Politik: Penghampiran "Diskursive Practice" dalam Yudi Latif dan Idi Subandy Ibrhami, Bahasa dan Kekuasaan: Politik Wacana di Panggung Orde Baru, Bandung: Mizan Irawanto, Budi, 2006. Menguak Tanda Membaca Kota: Ihwal Semiotika Kota, dalam Jurnal Balairung Mahasiswa Universitas Gadjah Mada. Edisi 40 hal 29

Sjairin, Syafri, 2004. "Minangkabau yang Gelisah" dalam Bandaro, dkk Minangkabau yang Gelisah Mencari Strategi Sosialisasi, Pewarisan, Adat dan Budaya Minangkabau untuk Generasi Muda, Bandung: Lubuk Agung 